\title{
Leverage about synthesis and dispersion with cuo nanoparticle in oil lubricating
}

\author{
Valdicleide Silva e Mello ${ }^{1}$, Ana Emília Diniz Silva Guedes ${ }^{1}$, Salete Martins Alves ${ }^{1}$, Tirso Lorenzo Reyes \\ Carvajal $^{2}$ \\ (valdkqi@hotmail.com;aedsguedes@gmail.com;saletealves@ect.ufrn.br;tirsolrca@gmail.com)
}

\author{
${ }^{1}$ Federal University of Rio Grande do Norte, Av. Senador Salgado Filho, 3000, Zip code 59078-970, Natal- RN, Brazil \\ ${ }^{2}$ Instituto de Tecnologia e Educação Galileo da Amazônia (ITEGAM). Av. Joaquim Nabuco. No 1950. Centro. Manaus - AM, \\ Brasil. Zip code 69005-080.
}

\begin{abstract}
The challenge for nanotechnology application in automotive lubrication is the difficulty in dispersing the nanoparticles in lubricating oils. Some factors have a direct influence on the dispersion of particles, such as size and shape, which are controlled by the chosen synthesis method. In addition, the use of covers and dispersant agents aid the dispersion of nanoparticles in lubricating oils. In this work studied the effect of different amount of energy given during the synthesis of nanoparticles in microwaves, in order to observe its influence on the dispersion size and shape of nanoparticles. They were covered with oleic acid, as well disperse in toluene, improving nanoparticle dispersion. The dispersion in of nanoparticles in oil was observed by physical characteristic, spectroscopy in the visible ultraviolet (UV/VIS) and micrographs (MO). The results showed that the synthesis with higher amount of energy generated a smaller particle size and better dispersion in oil. However the nanoparticle shape is not influenced by energy amount. The use of Oleic acid and toluene improved the dispersion of the nanoparticles in the lubricant oil as observed in the results of UV/ VIS by biggest interparticle distance.
\end{abstract}

Keywords: Nanoparticles, synthesis energy, dispersion in oil.

\section{Alavancagem sobre a síntese e dispersão com nanopartículas de $\mathrm{CuO}$ em óleo lubrificante}

\section{RESUMO}

O desafio para aplicação de nanotecnologia em lubrificação automóvel é a dificuldade em dispersar as nanopartículas em óleos lubrificantes. Alguns fatores têm uma influência direta sobre a dispersão de partículas, tais como tamanho e forma, que são controladas pelo método escolhido de síntese. Além disso, o uso de tampas e agentes dispersantes auxiliam na dispersão de nanopartículas em óleos lubrificantes. Neste trabalho foi estudado o efeito de diferentes quantidades de energia dada durante a síntese das nanopartículas em micro-ondas, a fim de observar a sua influência sobre o tamanho e a forma da dispersão de nanopartículas. Eles foram cobertas com ácido oleico, assim dispersar em tolueno, melhorando a dispersão de nanopartículas. A dispersão em de nanopartículas em óleo foi observada por característica física, espectroscopia no ultravioleta visível (UV/VIS) e micrografias (MO). Os resultados mostraram que a síntese de com maior quantidade de energia gerada uma dimensão de partícula mais pequena e melhor dispersão em óleo. No entanto, a forma de nanopartículas não é influenciada pela quantidade de energia. A utilização de ácido oleico e tolueno melhorou a dispersão das nanopartículas no óleo lubrificante como observado nos resultados de UV / VIS por maior distância interpartículas.

Palavras-Chave: nanopartículas, síntese de energia, dispersão em óleo.

\section{INTRODUCTION}

The friction reduction and anti-wear action of nanoparticles in lubricant have been reported as colloidal effect, rolling effect, protective film, and third body mechanisms [1]. However, the information about the tribological properties of nanofluids is still contradictory and in some cases the nanofluids show poorer behavior than the base fluid [2]. 
Valdicleide Silva e Mello, et al./ITEGAM-JETIA Vol.02, № 05, pp.53-60. Março, 2016.

Moreover, considering that nanofluids have different characteristics depending on several parameters (e.g. material, methodology of synthesis, size, shape and dispersion methodology of the nanoparticles) a huge research effort is required to identify and optimize nanofluids in relation to their application. To understand the behavior of nanoparticles and improve or to develop new applications are necessary to realize some investigations about the parameters that have influence on the stability and dispersion of nanoparticles.

The methodology of synthesis of nanoparticles by hydrothermal reactions assisted by microwaves has successful reported for to increasing the reaction kinetics, formation of metastable products, obtaining mono or polycrystals and synthesis of high purity product [3]. With this method is possible still the easy manipulation of parameters of the synthesis, such as energy (radiation) and temperature [4]. In the meantime in this method the growth rate of the products is too high for nanoparticles and, almost always, the product presents narrow particle size distribution as a consequence of fast and homogeneous nucleation [5].

Dispersing nanoparticles in oils is indeed a developing field of interest that provides promising multifunctional materials, for example for new lubricants with high tribological performance. But, this is not an easy task due the inorganic nanoparticles have poor disperse capacity therein [4].

The size of the particle is another factor that needs attention to anti wear additives in oils, which may affect the type of nanoparticles action mechanisms in lubricants. Smaller nanoparticles have been reported best results in applications with oils, due to their easy interaction with the surfaces of the friction pairs to form a surface protective film. When they are small and spherical shape, these nanoparticles are more likely to roll between the surfaces and change the sliding friction for a mixing of sliding and rolling friction. Thus, it is expected to find a relationship between the amount of energy given in the synthesis of nanoparticles on the size, since the power and the temperature of the synthesis could directly impact this parameter. In this work, we focus on investigation of the influence of synthesis energy on the size and dispersion of nanoparticles in oils.

\section{EXPERIMENTAL AND METHODS}

\section{II.1. SYNTHESIS AND CHARACTERIZATION OF NANOPARTICLES}

$\mathrm{CuO}$ nanoparticles were prepared from alcoholic solution of copper acetate, with $2 \mathrm{mmol}$ of copper acetate monohydrate were dissolved in $40 \mathrm{~mL}$ of ethanol; and an alcoholic solution of sodium hydroxide, being $8 \mathrm{mmol}$ of $\mathrm{NaOH}$ dissolved in $40 \mathrm{ml}$ of ethanol with the same stoichiometric ratio. In a teflon reactor were mixed $10 \mathrm{~mL}$ of each solution then inserted into the microwave reactor (Panasonic NN562BK) with a variation of energy conveyed in the synthesis of: Synthesis A: power of 99 Watts for $140 \mathrm{~s}$ with ON / OFF pulse 20 to $10 \mathrm{~s}$, the pulse being repeated nine times to make it possible to maintain the mixture at constant temperature of $80^{\circ} \mathrm{C}$; Synthesis B: power of 396 Watts per 140s, with a pulse on / off / on / off 30s, 20s, 10s and 20s pulse with repeated nine times to make it possible to maintain the mixture at constant temperature of $70^{\circ} \mathrm{C}$.; Synthesis C: power of 495 Watts 15 s with an average reaction temperature of $70^{\circ} \mathrm{C}$.

After this procedure, for all synthesis the reactor was cooled to $15^{\circ} \mathrm{C}$ for $5 \mathrm{~min}$ and it was recovered the solution. The nanoparticles were collected from these suspensions by centrifuging at $3600 \mathrm{rpm}$ for $5 \mathrm{~min}$. The collected material was washed several times with hot water and ethanol. Then, they were dried at $60^{\circ} \mathrm{C}$ for $2 \mathrm{~h}$ or until complete evaporation of ethanol. All synthesis was performed in triplicate.

Finally, the nanoparticles were coating to minimize the agglomeration by recover with $0.01 \mathrm{~g}$ of oleic acid to $0.2 \mathrm{~g}$ of $\mathrm{CuO}$ nanoparticles, which were added to $20 \mathrm{ml}$ of ethanol. The mixture were stirred for $2 \mathrm{~h}$ at $60{ }^{\circ} \mathrm{C}$ and then centrifuged for 10 minutes. Finally, they were dried for 2 hours or until complete evaporation of the ethanol. Afterwards, the produced samples were characterized by X-ray diffraction (XRD) and scanning electronic microscopy (SEM). The X-ray diffraction analyses were carried out using a XRD- 6000 powder diffractometer with $\mathrm{Cu} \mathrm{K} \alpha$ radiation, operating at $30 \mathrm{kV}$ and $30 \mathrm{~m}$, in the range from $20^{\circ}$ to $70^{\circ}$ with $0.02^{\circ} / \mathrm{min}$

Subsequently, the crystallite size was calculated using the Scherrer's equation:

$$
\text { Dhkl }=\mathrm{k} \lambda / \beta \cos \theta
$$

Where Dhkl is the crystallite size, $\mathrm{k}$ is the sphere shape factor (0.89), $\theta$ is the angle of the diffraction, $\beta$ is the full width at half maximum (FWHM) of the peak and $\lambda$ is the wavelength of X-ray

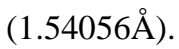

\section{II.2. DISPERSION ANALYSIS}

The nanoparticle dispersion in oil was analyzed by two methods: visual analyze in optical microscopy and using UV-VIS spectroscopy. The nanoparticles were added in PAO and $2 \mathrm{~mL}$ of toluene to $8 \mathrm{ml}$ of $\mathrm{PAO}$ with magnetic stirring for $6 \mathrm{~h}$ at $20^{\circ} \mathrm{C}$. After stirring this solvent was evaporated in a stove at $70^{\circ} \mathrm{C}$ for $24 \mathrm{~h}$. Then the suspensions were analyzed by optical microscopy (500x magnification) and UV-VIS spectroscopy. In the latter, the scan was performed in scan range 190 a $1100 \mathrm{~nm}$ in UV-VIS1650 Pc spectrophotometer Shimadzu. 


\section{RESULTS AND DISCUSSIONS}

\section{III.1 CHARACTERIZATION OF NANOPARTICLES}

The Figure 1 shows the diffraction patterns of the samples. For all synthesis pure phases were obtained and all diffraction peaks indexed to the mono- clinic structure with space group $\mathrm{Cc}(\mathrm{CuO})$ with the low intensity peaks with angles within the limits that characterize 35.7 to $38.5^{\circ}$ according [6],[7] and [8]. For [9] and [10] concluded that narrow and intense peaks seen in the XRD suggest that the material has high crystallinity and purity.

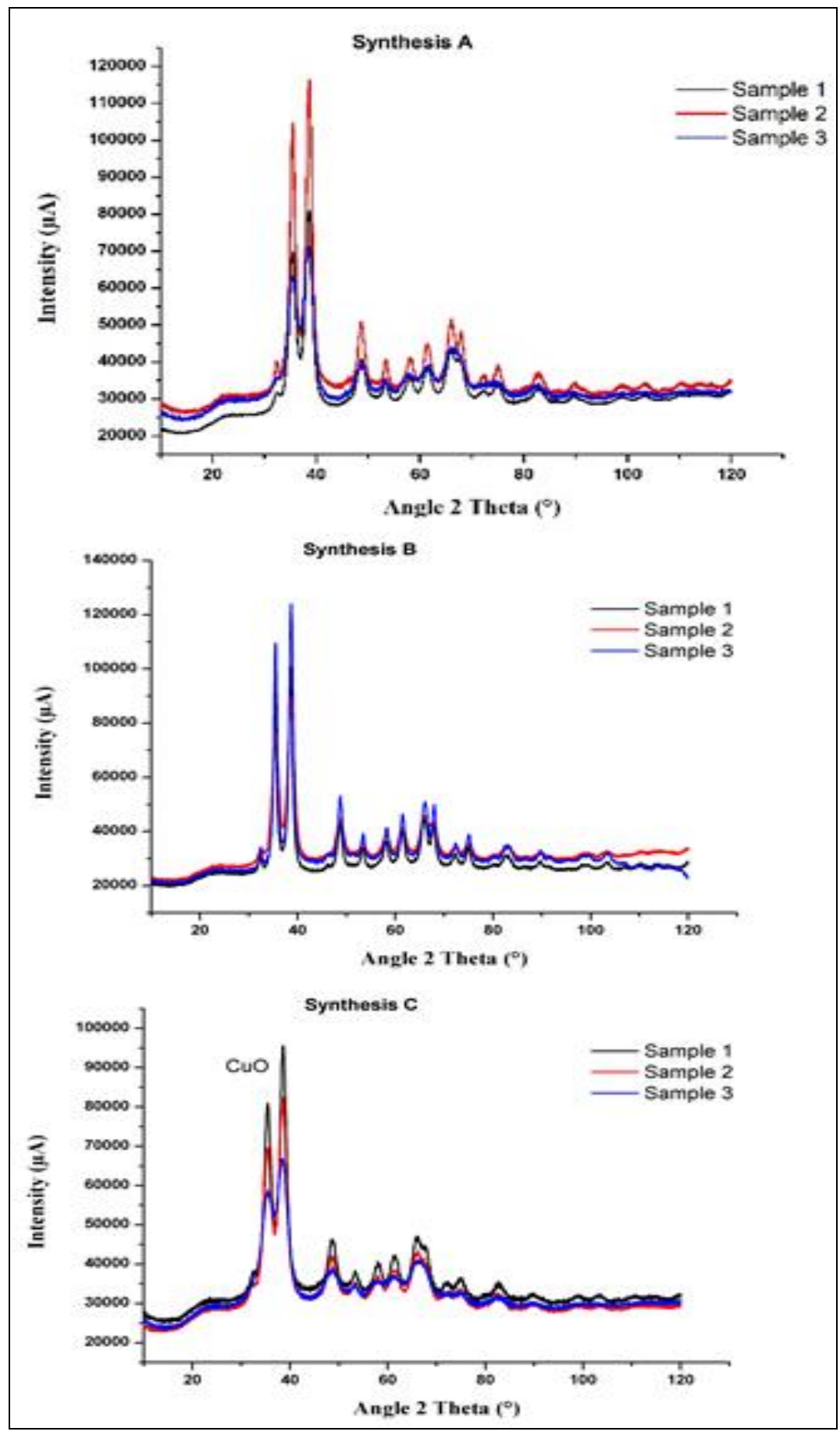

Figure 1: XRD spectrum to all synthesis.

All estimated particle sizes were below $10 \mathrm{~nm}$. The time and voltage parameters used for synthesizing $\mathrm{B}$ resulted in average size of $9 \mathrm{~nm}$. When the voltage is increased for the synthesis of $\mathrm{C}$, the average size was $4 \mathrm{~nm}$. With lower voltage and longer time exposure to radiation in the synthesis A, the average size resulted in $5.5 \mathrm{~nm}$. According [11] suggested that the treatment and manipulation of the microwave parameters synthesis have the ability to control the particle size. In our case, the smaller 
Valdicleide Silva e Mello, et al./ITEGAM-JETIA Vol.02, № 05, pp.53-60. Março, 2016.

particle sizes occur for power and exposure time manipulations which result in higher average temperatures throughout the synthesis. When the manipulation of these parameters results in a lower average temperature throughout the synthesis, the particle size was increased. This result corroborate those found by [12] and [8] when he used the same reaction group with synthesis temperature around $60{ }^{\circ} \mathrm{C}$. The XRD analysis suggests that the method was effective in producing $\mathrm{CuO}$ nanoparticles with repeatability and reproducibility.

From Figure 2 have the micrographs of Samples $\mathrm{CuO}$. Note the smaller agglomeration of particles when the power was increased. With the largest increase in power ( $\mathrm{C}$ synthesis) it is possible to identify particles in spherical shape.

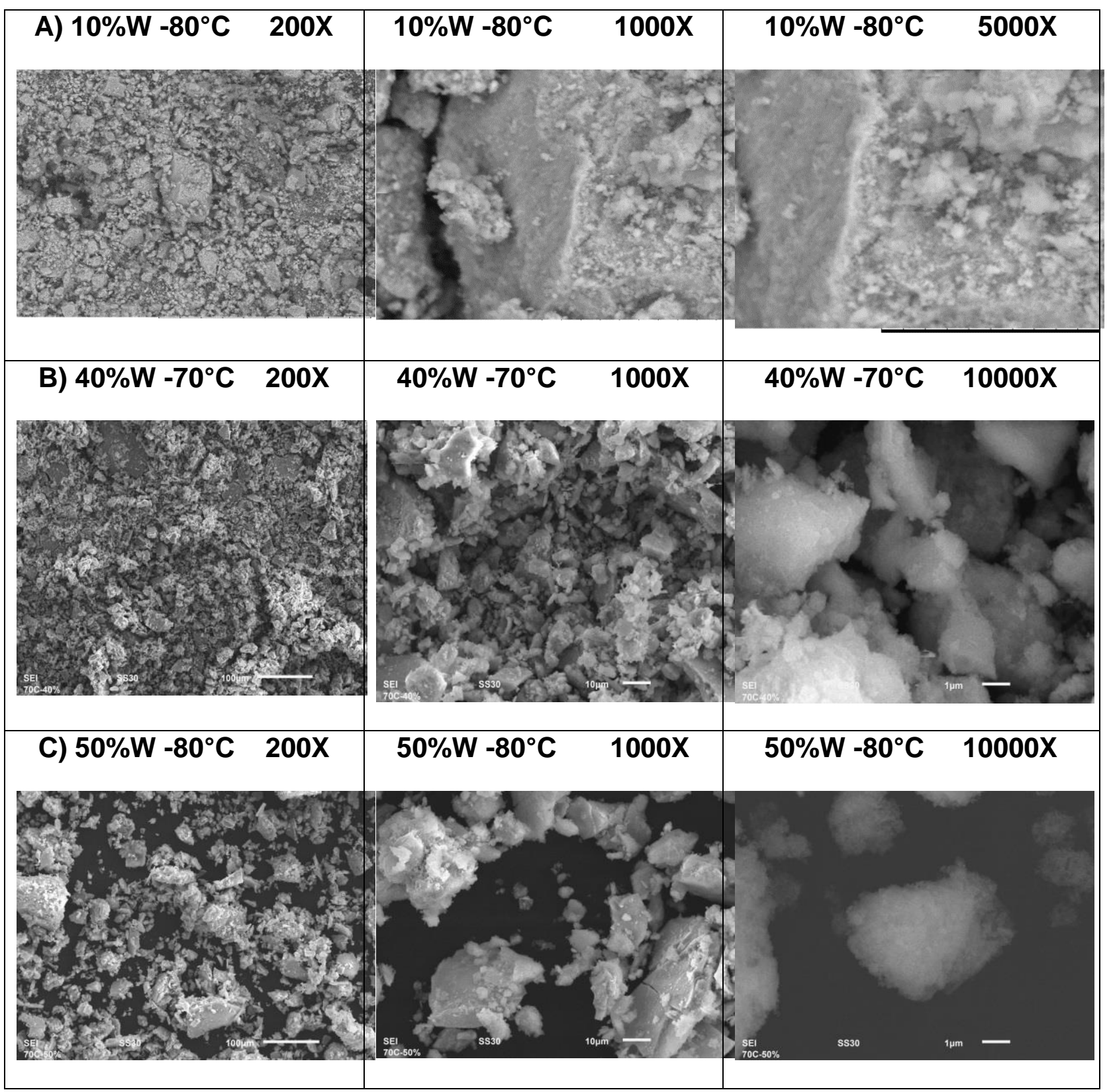

Figure 2: Micrographs $\mathrm{CuO}$ nanoparticles.

The smallest of agglomeration-like flakes particles are achieved in larger powers of synthesis, and were also achieved in the work of [13]. In their studies they found $\mathrm{VO}_{2}$ nanoparticles with low aggregation with the maximum power used in the synthesis (600W). A reason for this phenomenon was described by [14] justified by the increased surface enrichment due to thermal motion of liquid molecules in the field of microwave radiation.
The author suggests that manipulation of microwave synthesis parameters may reduce the particle size and increase uniformity of materials. Accordingly, the power increase in the synthesis provided more homogeneous particles due to the increased surface enrichment. Authors like [2],[8] obtained nanoparticles of $\mathrm{CuO}$ minimum size but with considerable agglomeration visible in the SEM images for metal oxides. According [7], synthetized $\mathrm{CuO}$ 
Valdicleide Silva e Mello, et al./ITEGAM-JETIA Vol.02, Nº 05, pp.53-60. Março, 2016.

nanoparticles with $800 \mathrm{~W}$ of power and obtained particles of low The results nanoparticle dispersion in PAO is shown in "Fig. 03". agglomeration. The poor dispersion of nanoparticles in oils is justified by the

III..2 PHYSICAL DISPERSION ANALYSIS ease of agglomeration that nanoparticles present by reason of their high surface tensions [15].

A) $10 \%-80^{\circ} \mathrm{C}$

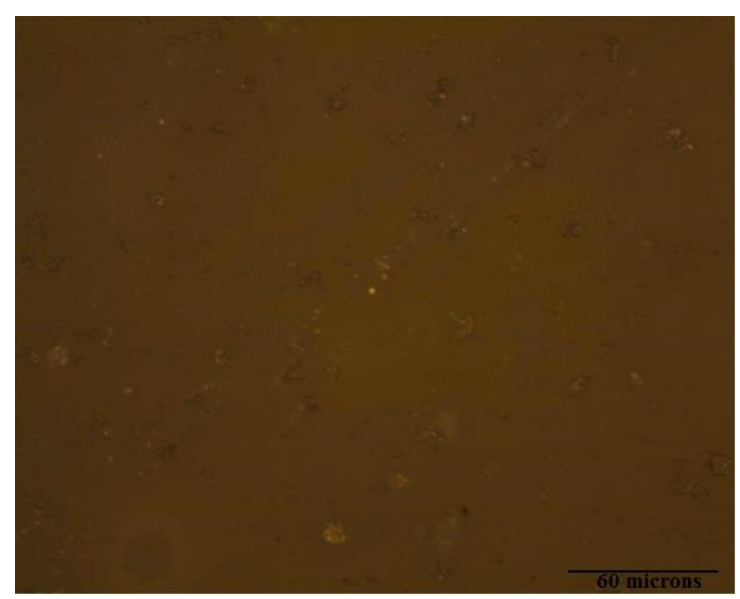

B) $40 \% \mathrm{~W}-70^{\circ} \mathrm{C}$

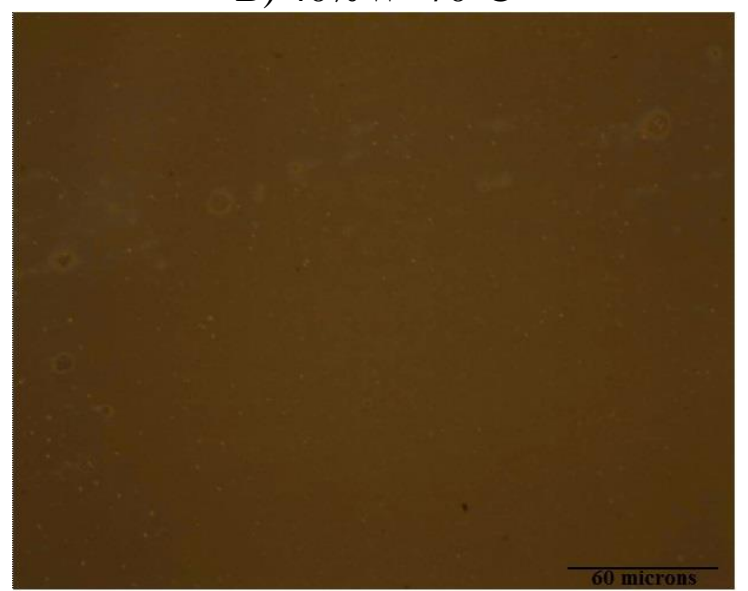

C) $50 \% \mathrm{~W}-80^{\circ}$

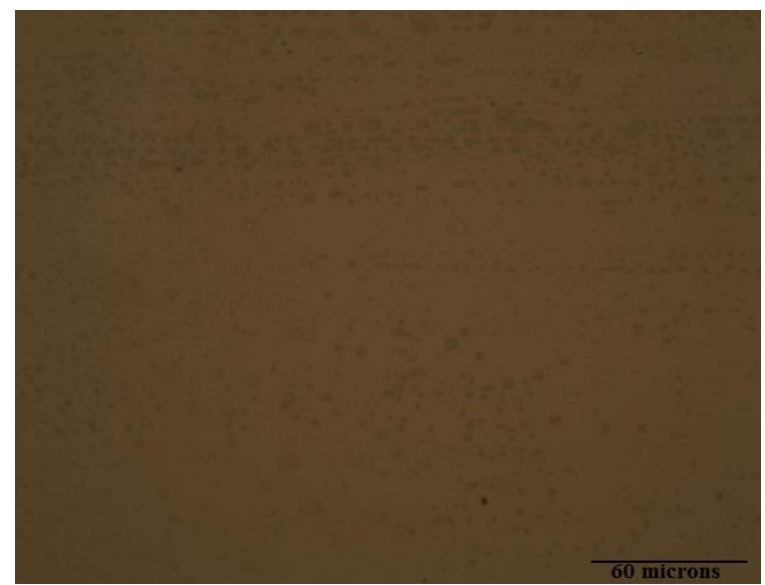

Figure 3: Suspensions of 0,1\% w $\mathrm{CuO}$ in PAO.

Homogeneous particles of the NNP C showed better dispersions so it was not possible to identify the presence of agglomerates of these nanoparticles in the micrograph, only microdroplets of
PAO were observed. These result indicate that nanoparticle $\mathrm{C}$ had higher solubility with the oil, when used toluene as dispersant agent. The homogeneous characteristic of particles 
directly influenced the dispersion in oil as described by [14]. However, the agglomeration is still persistent for NNP A and B, since it is still possible to see the particulate in the micrographs with optical increased 500x. For [16] found poor dispersion of MoS2 in vegetable oil and paraffinic oil without use of surfactant and they suggested that the verification of nanoparticle dispersion in the oils needs to be carried out to recommend its deployment in long term stationary applications.

\section{III.3 SPECTROSCOPY DISPERSION ANALYSIS}

The dispersion analysis by UV vis "Fig. 04" confirms that all nanoparticles are indeed cupric copper oxide because copper nanoparticles should show a characteristic peak of plasmon resonance at around 600nm [17],[18],[6] and [19]. The absence of strong band plasmon absorption at that wavelength proves the effectiveness of the synthesis of copper oxides formation. This result converges with the results shown in the XRD spectra shown above. This analysis also suggests that the particles exhibit behavior spherical his result converges with the results shown in the XRD spectra shown above. This analysis also suggests that the particles exhibit behavior of spherical particles by the lack of a second absorption band. According [20] nonspherical particles must present two oscillations, a transverse and another longitudinal, generating two absorption bands.

The resonance plasmon spectrum (SPR) of samples show characteristic band of copper oxide in the spectral region between $240-300 \mathrm{~nm}$, corroborating the results of [21],[22] and [23].

The largest intensities of peaks found to $\mathrm{A}$ and $\mathrm{C}$ nanoparticles indicate a decreased particle-particle and larger interparticle distances, so that these are more well-spaced [24][28].

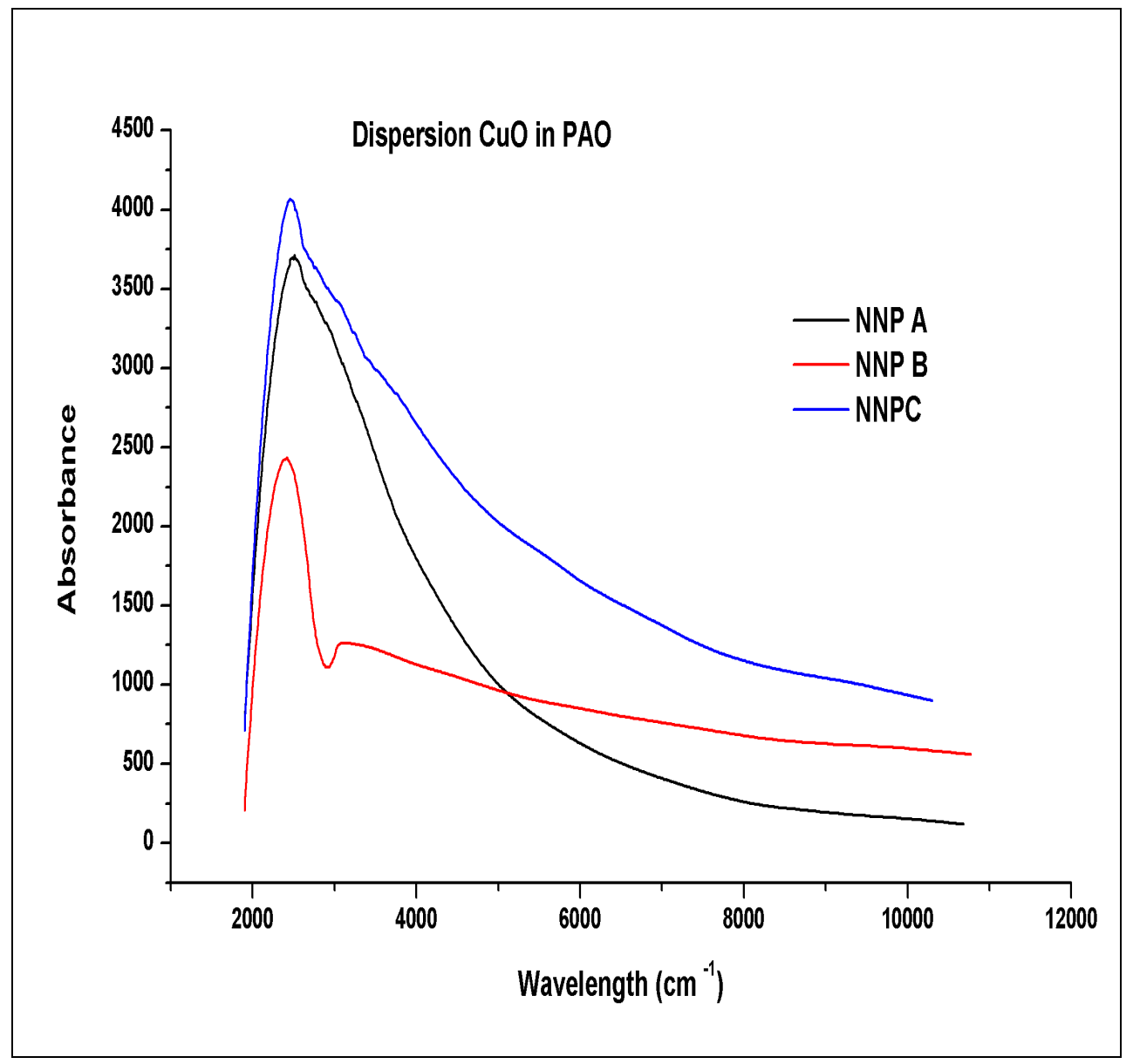

Figure 4: Suspensions of $0,1 \% \mathrm{w} \mathrm{CuO}$ in PAO.

In case NNP B suspension the particles are destabilized, when this occurs the original extinction peak will decrease in intensity due to the depletion of stable nanoparticles), and often the peak will broaden or a secondary peak will form at longer wavelengths (due to the formation of aggregates) [29]. For larger particles the oscillations are small and decrease with increasing size [25]; [26]. For [27] attribute the decrease of absorbance peaks to the large degree of particle aggregation. 
Valdicleide Silva e Mello, et al./ITEGAM-JETIA Vol.02, № 05, pp.53-60. Março, 2016.

\section{CONCLUSIONS}

All the parameters investigated in this work was effective in producing $\mathrm{CuO}$ nanoparticles with repeatability and reproducibility. The smaller particle sizes occur for power and exposure time manipulations which result in higher average temperature throughout the synthesis.

The homogeneous and less agglomerated particles were found when the power was increased. Nanoparticles smaller showed better dispersion in oil when used toluene in the method to the addition. The manipulation of microwave synthesis parameters may reduce the particle size, increase uniformity of materials and affect the agglomeration of particles in oils.

The highest power condition (495W) was more effective in improving the dispersion of the nanoparticles either alone or when added in oils.

\section{ACKNOWLEDGEMENTS}

The authors wish to express thanks to the LAMEN, Analytics Chemical and Tribology laboratories of UFRN by the availability of equipment for test, and the Samara Leandro for their support in the preparation of test specimens.

\section{REFERENCES}

[1] Chiñas-Castillo. F, Spikes, H. A., 2000. "The behavior of colloidal solid particles in elastohydrodynamic contacts". Tribology Transactions. Vol. 43 /3. p. 387-94.

[2] Alves, S.M., Barros, B.S.,Trajano ,M.F., Ribeiro, K.S.B., Moura, E.Y., 2013."Tribological behavior of vegetable oilbased lubricants with nanoparticles of oxides in boundary lubrication conditions". Tribology Internacional. Vol. 65 , p. $28-36$.

[3] Volanti, D. P., 2011. Morfologias de óxido de cobre (II) na mesoescala: síntese hidrotérmica assistida por micro-ondas, mecanismo de crescimento e atividade catalítica na reação de desidrogenação do etanol. Tese. Universidade Estadual Paulista. Araraquara.

[4] Chen D., Tang, K., Shen, G., 2003. "Microwave-assisted synthesis of metal sulfides in ethylene glycol". Materials Chemistry and Physic. Vol. 82, p. 206-209.

[5] Jansen, J. C., Arafat, A., Barakat, A. K., Van Bekkum, H., 1992. "Microwave synthesis of nanocrystalline metal sulfides in formaldehyde solution". In Synthesis of Microporous Materials. M. L. Occelli and H. E. Robson, chapter 33, p. 507521, Van Nostrand Reinhold, New York, $1^{\text {st }}$ edition.

[6] Urquieta-González, E.A., Martins, L., Peguin, R.P.S., Batista, M.S., 2002. "Identification of extra-frame work species on Fe/ZSM-5 and Cu/ZSM-5 catalysts typical microporous molecular sieves with zeolitic structure". Materials Research. Vol. 5/ 3, p. 321-327.
[7] Rejith,S.G. , Krishnan, C., 2013. "Optical, thermal and magnetic studies on zinc-doped copper oxide nanoparticles". Materials Letters . Vol. 106, p.87-89.

[8] Wang, H., Xu, J.Z., Zhu, J.Jie., Chen, H.Y., 2002. "Preparation of $\mathrm{CuO}$ nanoparticles by microwave irradiation". Journal of Crystal Growth . Vol. 244. p. 88-94.

[9] Liu, X., Geng, B., Du,Q.,Ma, J., Liu, X., 2004. "Temperature-controlled self-assembled synthesis of $\mathrm{CuO}$, $\mathrm{Cu} 2 \mathrm{O}$ and $\mathrm{Cu}$ nanoparticles through a single-precursor route". Materials Science and Engineering A. Vol. 448, p. 7 14.

[10] Barbalho, D.S.T., 2007. Síntese, caracterização e aplicação de catalisadores mistos contendo Cobalto e Cobre. p. 89 Dissertação. Universidade Federal de Brasília, Brasília.

[11] Jamil, M. R., Ahmad, A., Hafeez, Z. U., Haq, N. A., 2008. "Microwave assisted synthesis of fine magnetic manganese ferrite particles using co-precipitation technique". Pakistan Journal of Agricultural Sciences, Vol. 45/ 3, p. 59-64.

[12] Medeiros, A.A.S., Mello, V.S., Trajano, M.F., Barros, B.S., Alves, S.M., 2014. "Influencia da energia de síntese nas propriedades físicas de óxidos". In $21^{\circ}$ Congresso Brasileiro de Engenharia e Ciência dos Materiais. Mato Grosso do Sul, Brazil.

[13] Phoempoon, P., Sikong, L., 2014. "Phase Transformation of $\mathrm{VO}_{2}$ Nanoparticles Assisted by Microwave Heating". The Scientific World Journal. Vol. 2014, p.1- 8.

[14] Rybakov,K. I., Eremeev, A.G., Egorov, S.V., Bykov, Y. V., Pajkic,Z., Willert-Porada, M., 2008. "Effect of microwave heating on phase transformations in nanostructured alumina". Journal of Physics D. Vol. 41/10. p. 1-4.

[15] Xu, R., 2008. "Progress in nanoparticles characterization: Sizing and zeta potential measurement". Particuology . Vol. 6, p. 112-115.

[16] Koshy, C. P., Rajendrakumar, P. K., Thottackkad, M. V.,2015. "Evaluation of the tribological and thermo-physical properties of coconut oil added with MoS2 nanoparticles at elevated temperatures". Wear in press

[17] Dong, C., Cai, H., Zhang, X., Cao, C., 2014. "Synthesis and characterization of monodisperse copper nanoparticles using gum acacia”. Physica E, Vol. 57, p. 12-20.

[18] Zhang, S., Peng, B., Yang, S., Wang, H., Yu, H., Fang, Y., Peng, F., 2015. "Non-noble metal copper nanoparticlesdecorated $\mathrm{TiO2}$ nanotube arrays with plasmon-enhanced photocatalytic hydrogen evolution under visible light". Intenational jornal of hydrogen energy. Vol. 40, p. 303-310.

[19] Marimuthu, A., Zhang, J., Linic, S., 2013. "Tuning selectivity in propylene epoxidation by plasmon mediated 
photoswitching of Cu oxidation state”. Science. Vol. 339, p. 159-163.

[20] Liz-Marzán, L.M., 2004. "Nanometals: formation and color". Mater. Today, p. 26-31.

[21] Sankar, R., Manikandan, P., Malarvizhi, V., Fathima, T., Shivashangari, K.S, Ravikumar, V., 2014. "Green synthesis of colloidal copper oxide nanoparticles using Carica papaya and its application in photocatalytic dye degradation". Molecular and Biomolecular Spectroscopy. Vol. 121, p. 746-750.

[22] Logar, M., Bracko, I., Potocnik,A., Jancar, B., 2014. "Cu and $\mathrm{CuO}$ /Titanate Nanobelt Based Network Assemblies for Enhanced Visible Light Photocatalysis". Langmuir. Vol. 30, p. 4852-4862.

[23] Zhang, D., Yang, D., 2013. "Gelatin-stabilized copper nanoparticles: Synthesis, morphology, and their surfaceenhanced Raman scattering properties". Physica B, Vol. 415, p. 44-48.

[24] Otubo, L., 2003. Técnicas de caracterização de nanopartículas metálicas funcionalizadas. Monografia. Universidade Estadual de Campinas. São Paulo.

[25] Yeshchenko, O.A, Bondarchuk, I.S., Gurin, V.S., Dmitruk,I.M., Kotko, A.V., 2013. “Temperature dependence of the surface plasmon resonance in gold nanoparticles". Surface Science. Vol.608, p. 275-281.

[26] Nanocomposix, 2012. "Uv/vis/ir spectroscopy analysis of nanoparticles". Ronson CT Ste K, 21 Sep. 2012 < http://nanocomposix.com>.

[27] Munkhbayar,B., Tanshen, M.R., Chung, J. J., Jeong, H. H., 2013. "Surfactant-free dispersion of silver nanoparticles into MWCNT-aqueous nanofluids prepared by one-step technique and their thermal characteristics". Ceramics International. Vol. 39, p. 6415-6425.

[28] Guo, X., Hao, C., Jin, G., Zhu, H.Y., Guo, X.Y., 2014. "Copper nanoparticles on graphene support: an efficient photocatalyst for coupling of nitroaromatics in visible light". Angew Chem Int. Vol.53, p. 1973-1977.

[29] Yang, G.B., Chai, S.T., Xiong, X.J., Zhang, S.M., Yu, L.G., Zhang, P.Y., 2012. "Preparation and tribological properties of surface modified CuO nanoparticles". Trans. Nonferrous Met. Soc. Vol.22, p. 366-372. 